\title{
Physiological effect of a food additive on some haematological and biochemical parameters of male albino rats
}

\author{
Mohammed S. AL-Shinnawy \\ Biological and Geological Sciences Department, Faculty of Education, Ain Shams \\ University, Cairo, Egypt.
}

\begin{abstract}
Food additives are used for various purposes, including preservation, colouring and sweetening. Some food additives, however, have been prohibited from use because of their toxicity. Azo dyes are one of these food additives which widely used as colorants in foods. The extent of such use is related to the degree of industrialization of the society. Approximately $1-5 \times 10^{5}$ pounds of the dye amaranth were used each year in over 60countries.

The present study aimed to investigate the possible influence impacts of amaranth (red dye) on some hematological and biochemical parameters of male albino rat, Rattus norvegicus . So, sixty adult male rats weighing 100-110gm. were divided into 3groups, the first one served as a control, the second received $25 \mathrm{mg} / \mathrm{kg}$ of amaranth and the third group was treated with $75 \mathrm{mg} / \mathrm{kg}$ of amaranth. Rats were treated orally for 30days followed a recovery for another 30days.

The obtained data reveal a marked decrease in the percentage of body weight gain, red blood cells (R.B.Cs) counts, Hemoglobin ( $\mathrm{Hb})$ content, mean corpuscular hemoglobin concentration (MCHC), serum total lipids and serum total cholesterol of rats treated with the high dose of amaranth. On the other hand, a noticeable increase in hematocrit (Hct) value, Mean corpuscular volume (MCV), activities of Serum aspartate aminotransferase (AST), alanine aminotransferase (ALT), alkaline phosphatase (ALP), glucose level, serum total protein and globulin were found in rats treated with the high dose of amaranth. In general, there was appreciable improvement after the recovery period.
\end{abstract}

Key Words: Food additives, Amaranth, Hematological and Biochemical Parameters, Albino Rat, Serum.

\section{INTRODUCTION}

The wide range of food additives, running into more than 2,5000 items used to preserve, dye or enhance foods (Hirschbruch \& Torres, 1998 and Toledo, 1999) are a consequence of industrialization and the development of food processing technology. The great bulk of artificial colourings used in food are synthetic dyes. For decades synthetic food dyes have been suspected of being toxic or carcinogenic and many have been banned whenever possible, choose foods without dyes. They are mostly used in foods of questionable nutrition worth anyway.

Many researchers (Reyes et al., 1996; Tanaka, 2005 and Zraly et al., 2006) studied the metabolic and toxicological disorders induced by the administration of specific food colourant additives to rats and other mammals. Many azo compounds are genotoxic in short-term tests and carcinogenic in laboratory animals (Combes \& Haveland - Smith, 1982 and Sasaki et al., 2002). 
Amaranth is most common red colouring used in food, drugs and cosmetics and its safety is currently being reinvestigated in view of its suggested carcinogenic and teratogenic effect (Larsson, 1975 and Holmberg, 1978).

In 2001, Tsuda, et al. reported that amaranth and allura red induce colon DNA damage at a very low dose in mice. Yet further investigations are required from other points of view in order to confidently predict the potential danger of these food dyes to mankind. The present study was aimed to determine the effect of amaranth on some hematological and biochemical parameters in male albino rats. Also, the study is an attempt to determine if high doses of amaranth can affect in liver and kidney functions.

\section{MATERIALS AND METHODS}

\section{Synthetic dye used:}

Amaranth:

- Synthetic azo dye. - Red food colour. - Very soluble in water.

Chemical name:

3-hydroxy-4-[C4-sulfo-1-naphthalenyl)azo]-2,7-naphthalenedisulfonicacid,trisodium alt. - INS:123 - (915-67-3) - Dye content-1010570 - MW: 604.46

- Formula : $\mathrm{C}_{20} \mathrm{H}_{11} \mathrm{~N}_{2} \mathrm{Na}_{3} \mathrm{O}_{10} \mathrm{~S}_{3}$

Sixty mature male albino rats Rattus norvegicus ranging in weight from 100$110 \mathrm{gm}$. were essentially obtained from Schistosama Biological Supply Program (SBSP), Theodor Bilharz Research Institute. The rats were kept under normal laboratory conditions, fed on standard diet and water ad libitum. All rats were starved for $12 \mathrm{hrs}$ before treatment, but allowed free excess to water. They were allocated at random into two groups: The first group (20rats) were considered as controls . The second group (40 rats) were in turn-assigned into equal subgroups (i.e.20 rats each). Rats in the first subgroup were orally administered a dose of $25 \mathrm{mg} / \mathrm{kg}$ body weight/day of amaranth. Rats in the second subgroup were treated orally with a dose of $75 \mathrm{mg} / \mathrm{kg}$ body weight/day of amaranth. After 30 days of treatment 10 rats were chosen randomly from each group and sacrificed. The rest of rats were left without any treatment for further 30 days as a recovery period after which the last batch of rats was sacrificed to assay the impact of recovery.

All of the control and treated rats were individually weighed in order to detect any change that may take place in their body weights. The percentage of body weight gain was calculated as follows:

Mean final weight - Mean initial weight

\section{Hematological studies:}

Mean initial body weight

A part of blood samples were collected on heparinized capillary tubes for hematocrit value which was determined according to the method of Rodak (1995). Another part of blood was collected on EDTA for the hematological experimentation .Red and white blood cells counts were performed using improved hemocytometer according to Dacie and Lewis (1991). Hemoglobin concentration was estimated according to Dacie and Lewis (1991). Mean corpuscular volume (MCV), mean corpuscular hemoglobin $(\mathrm{MCH})$ and mean corpuscular hemoglobin concentration (MCHC) were calculated according to Dacie and Lewis (1993).

\section{Biochemical analysis:}

Samples of blood were withdrawn and left to clot in a clear dry centrifuge tubes for each rat, then centrifuged at 3500 r.p.m. for 15 minutes. A portion of the clear 
supernatant serum was used immediately for glucose determination according to the enzymatic colorimetric method described by Trinder (1969).

The remaining serum was frozen at $-20^{\circ} \mathrm{C}$ for subsequent analysis. Serum aspartate aminotransferase (AST) and alanine aminotransferase (ALT) activities were estimated according to the method described by BergMeyer and Bernt(1974). Serum alkaline phosphatase (ALP) was determined by the method of Belfield and Golbderg (1971). Serum contents of total cholesterol and total lipids were assayed according to Allain, et al. (1974) and knight, et al. (1972), respectively. Serum total protein and albumin levels were estimated according to the methods described by Doumas (1975) and Doumas, et al. (1971), respectively. Serum globulin was calculated according to Lanter (1975). Serum content of urea and creatinine were estimated according to the methods described by Patton \& Crouch (1977) and Bartels \&Bohmer (1972), respectively.

\section{Data analysis:}

The obtained results were statistically analyzed by using the student "t"-test according to the method of Snedecor and Cochran (1980).

\section{RESULTS}

The data represented in table (1) display the effect of treatment with amaranth on the percentage of body weight gain of male albino rats. The findings revealed a significant decrease of body weight $(\mathrm{P}<0.05)$ after 30days treatment with the low dose $(25 \mathrm{mg} / \mathrm{kg})$ of amaranth and recorded a highly significant decrease $(\mathrm{P}<0.01)$ with the high dose after $(75 \mathrm{mg} / \mathrm{kg})$. These results remain significantly decrease $(\mathrm{P}<0.05)$ after the recovery period.

Table (1): Effect of treatment with amaranth on the percentage of body weight change of male albino rats.

\begin{tabular}{||c||c||c||}
\hline Groups & $\begin{array}{c}\text { Body weight change } \\
\text { After 30 days } \\
\text { (treatment) }\end{array}$ & $\begin{array}{c}\text { Body weight change } \\
\text { After 30 days } \\
\text { (recovery period) }\end{array}$ \\
\hline \hline Control & $42.68 \pm 1.03$ & $84.52 \pm 2.62$ \\
\hline $\begin{array}{c}\text { Amaranth } \\
(\mathbf{2 5 m g / k g )}\end{array}$ & $39.14 \pm \pm^{*} 0.97$ & $75.87 \pm \pm^{*} 2.09$ \\
\hline $\begin{array}{c}\text { Amaranth } \\
(\mathbf{7 5 m g} / \mathbf{k g})\end{array}$ & $31.34 \pm^{* *} 2.13$ & $73.14 \pm{ }^{*} 1.98$ \\
\hline
\end{tabular}

All values were expressed as mean \pm standard error.

$*$ (Significant). ** (Highly Significant).

Results presented in table 2 show the alterations of the various hematological parameters in the blood of the studied rats induced by amaranth. Rats supplemented with $75 \mathrm{mg} / \mathrm{kg}$ of amaranth exhibited highly significant decrease $(\mathrm{P}<0.01)$ in red cell count (R.B.Cs) and the mean corpuscular hemoglobin concentration (MCHC). Also, the same dose recorded a significant decrease $(\mathrm{P}<0.05)$ in hemoglobin $(\mathrm{Hb})$ content. But treatment with this dose of amaranth showed a highly significant $(\mathrm{P}<0.01)$ increase in the mean corpuscular volume $(\mathrm{MCV})$ and a significant increase $(\mathrm{P}<0.05)$ in the hematocrit (Hct) value. Same results of R.B.Cs , Hb, MCV and MCHC are recorded in the recovery groups. Whereas, Leucocytes (W.B.Cs) counts and the mean corpuscular hemoglobin $(\mathrm{MCH})$ of albino rats were not affected by amaranth throughout the experiment. 
Table (2): Blood picture values of male albino rats treated with amaranth .

\begin{tabular}{|c|c|c|c|c|c|c|c|}
\hline Groups & $\underset{\left(\times 10^{6} / \mathbf{m m}^{3}\right)}{\text { R.B.Cs }}$ & $\begin{array}{c}\mathbf{H b} \\
\text { (g/dl) }\end{array}$ & $\begin{array}{l}\text { Het } \\
(\%)\end{array}$ & $\begin{array}{c}\text { MCV } \\
\text { (FL) }\end{array}$ & $\begin{array}{c}\text { MCH } \\
(\mathbf{p g})\end{array}$ & $\begin{array}{c}\text { MCHC } \\
(\%)\end{array}$ & 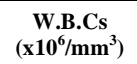 \\
\hline \multicolumn{8}{|c|}{ After 30 days (treatment) } \\
\hline Control & $8.3 \pm 0.04$ & $14.41 \pm 0.31$ & $38.40 \pm 1.32$ & $46.27 \pm 0.18$ & $17.36 \pm 0.18$ & $37.53 \pm 0.83$ & $4.97 \pm 0.98$ \\
\hline $\begin{array}{l}\text { Amaranth } \\
(25 \mathrm{mg} / \mathrm{kg})\end{array}$ & $8.4 \pm{ }^{\mathrm{NS}} 0.06$ & $14.62 \pm{ }^{\mathrm{NS}} 0.22$ & $38.50 \pm{ }^{\mathrm{NS}} 1.36$ & $45.83 \pm{ }^{\mathrm{NS}} 0.72$ & $17.40 \pm{ }^{\mathrm{NS}} 0.14$ & $38.00 \pm \pm^{\mathrm{NS}} 0.81$ & $5.03 \pm{ }^{\mathrm{NS}} 1.20$ \\
\hline $\begin{array}{l}\text { Amaranth } \\
(75 \mathrm{mg} / \mathrm{kg})\end{array}$ & $7.4 \pm \pm^{* * *} 0.12$ & $13.05 \pm 0.45$ & $41.90 \pm{ }^{*} 1.04$ & $56.62 \pm^{* * *} 0.59$ & $17.64 \pm \pm^{\mathrm{NS}} 0.29$ & $31.15 \pm{ }^{* *} 0.76$ & $5.81 \pm{ }^{\mathrm{NS}} 1.71$ \\
\hline \multicolumn{8}{|c|}{ After 30 days (recovery period) } \\
\hline Control & $8.5 \pm 0.09$ & $14.35 \pm 0.42$ & $37.60 \pm 1.61$ & $44.23 \pm 0.86$ & $16.88 \pm 0.26$ & $38.16 \pm 1.04$ & $4.36 \pm 1.03$ \\
\hline $\begin{array}{l}\text { Amaranth } \\
(25 \mathrm{mg} / \mathrm{kg})\end{array}$ & $8.3 \pm \pm^{\mathrm{NS}} 0.08$ & $14.43 \pm{ }^{\mathrm{NS}} 0.39$ & $38.10 \pm{ }^{\mathrm{NS}} 1.57$ & $45.90 \pm \pm^{\mathrm{NS}} 0.83$ & $17.39 \pm{ }^{\mathrm{NS}} 0.24$ & $37.87 \pm^{\mathrm{NS}} 1.00$ & $5.21 \pm{ }^{\mathrm{NS}} 1.74$ \\
\hline $\begin{array}{l}\text { Amaranth } \\
(75 \mathrm{mg} / \mathrm{kg})\end{array}$ & $8.0 \pm * 0.1$ & $13.29 \pm 0.17$ & $41.2 \pm^{\mathrm{NS}} 1.22$ & $51.5 \pm^{* *} 0.67$ & $16.61 \pm{ }^{\mathrm{NS}} 0.14$ & $32.26 \pm^{* * *} 0.71$ & $5.13 \pm{ }^{\mathrm{NS}} 1.60$ \\
\hline
\end{tabular}

All values were expressed as mean \pm standard error.

NS (Insignificant) *(Significant). ** (Highly Significant).

The data represented in table 3 display the effect of treatment with amaranth on enzymatic activities which reflect the liver function of male albino rats. A highly significant increase $(\mathrm{P}<0.01)$ in aspartate aminotransferase (AST) and alanine aminotransferase (ALT) was detected in groups treated with the high dose of amaranth; these results were continued after a recovery period. This elevation was also recorded in groups treated with the low dose of amaranth which revealed a significant increase $(\mathrm{P}<0.05)$. Obvious amelioration appeared in AST and ALT activities in groups treated with the low dose after the recovery period. A significant increase $(\mathrm{P}<0.05)$ in alkaline phosphatase (ALP) activity was also detected in groups treated with the high dose of amaranth in both treated and recovery groups.

Table (3): Effect of treatment with amaranth on some serum enzymes activities indicative of liver function of male albino rats.

\begin{tabular}{|c|c|c|c|}
\hline Groups & AST(U/ml) & ALT(U/ml) & $\mathbf{A L P}(\mathbf{U} / \mathbf{l})$ \\
\hline \multicolumn{4}{|c|}{ After 30 days (treatment) } \\
\hline Control & $164.95 \pm 0.17$ & $63.68 \pm 1.02$ & $94.65 \pm 4.25$ \\
\hline Amaranth $(25 \mathrm{mg} / \mathrm{kg})$ & $168.11 \pm *^{*} 1.13$ & $68.34 \pm \pm^{*} 1.54$ & $100.85 \pm{ }^{\mathrm{NS}} 6.85$ \\
\hline Amaranth (75mg/kg) & $179.11 \pm{ }^{* * *} 1.04$ & $74.34 \pm{ }^{* *} 1.68$ & $115.10 \pm{ }^{*} 3.15$ \\
\hline \multicolumn{4}{|c|}{ After 30 days (recovery period) } \\
\hline Control & $163.70 \pm 0.19$ & $64.07 \pm 1.13$ & $95.75 \pm 4.81$ \\
\hline Amaranth (25mg/kg) & $165.00 \pm{ }^{\mathrm{NS}} 0.93$ & $66.93 \pm{ }^{\mathrm{NS}} 1.39$ & $101.64 \pm{ }^{\mathrm{NS}} 3.09$ \\
\hline Amaranth (75mg/kg) & $167.40 \pm \pm^{* *} 0.71$ & $71.81 \pm{ }^{* *} 1.94$ & $112.97 \pm \pm^{*} 3.12$ \\
\hline
\end{tabular}

Table 4 shows the changes in serum total lipids, total cholesterol and glucose levels. The data revealed a significant elevation $(\mathrm{P}<0.05)$ in these parameters in groups treated with the high dose of amaranth only which continued after the recovery period in both total cholesterol and total lipids, but the glucose levels returned around its normal values after the recovery period. 
Table (4): Effect of treatment with amaranth on serum total cholesterol, total lipids and glucose levels of male albino rat.

\begin{tabular}{|c|c|c|c|}
\hline Groups & $\begin{array}{c}\text { Serum total lipids } \\
(\mathrm{mg} / \mathrm{dL})\end{array}$ & $\begin{array}{c}\text { Serum total cholesterol } \\
(\mathrm{mg} / \mathrm{dL})\end{array}$ & $\begin{array}{c}\text { Serum glucose level } \\
(\mathrm{mg} / \mathrm{dL})\end{array}$ \\
\hline \multicolumn{4}{|c|}{ After 30 days (treatment) } \\
\hline Control & $233.70 \pm 4.82$ & $83.34 \pm 2.91$ & $78.55 \pm 1.44$ \\
\hline $\begin{array}{l}\text { Amaranth } \\
(25 \mathrm{mg} / \mathrm{kg})\end{array}$ & $228.13 \pm \pm^{\mathrm{NS}} 3.91$ & $79.16 \pm \pm^{\mathrm{NS}} 3.13$ & $80.31 \pm{ }^{\mathrm{NS}} 1.60$ \\
\hline $\begin{array}{l}\text { Amaranth } \\
(75 \mathrm{mg} / \mathrm{kg})\end{array}$ & $217.91 \pm * 3.07$ & $74.03 \pm \pm^{*} 2.64$ & $84.95 \pm \pm^{*} 2.70$ \\
\hline \multicolumn{4}{|c|}{ After 30 days (recovery period) } \\
\hline Control & $237.14 \pm 4.33$ & $87.14 \pm 2.24$ & $76.70 \pm 1.49$ \\
\hline $\begin{array}{l}\text { Amaranth } \\
(25 \mathrm{mg} / \mathrm{kg})\end{array}$ & $231.65 \pm{ }^{N S} 4.01$ & $81.83 \pm{ }^{\mathrm{NS}} 2.16$ & $77.14 \pm{ }^{\mathrm{NS}} 1.81$ \\
\hline $\begin{array}{l}\text { Amaranth } \\
(75 \mathrm{mg} / \mathrm{kg})\end{array}$ & $224.85 \pm 4.17$ & $78.96 \pm \pm^{*} 2.37$ & $80.75 \pm{ }^{\mathrm{NS}} 2.11$ \\
\hline
\end{tabular}

All values were expressed as mean \pm standard error.

NS (Insignificant).

* (Significant).

Table 5 demonstrated the effect of amaranth on total serum proteins, albumin, globulin levels and $\mathrm{A} / \mathrm{g}$ ratio. The two doses of amaranth caused a significantly increase $(\mathrm{P}<0.05)$ in serum total proteins only as compared with the corresponding control group. However, treating rats with the high dose caused a significantly increase $(\mathrm{P}<0.05)$ in serum globulin. No significant was recorded in all these parameters after the recovery period.

Table (5): Effect of treatment with amaranth on serum total proteins, albumin, globulin and $\mathrm{A} / \mathrm{g}$ ratio of male albino rats.

\begin{tabular}{|c|c|c|c|c|}
\hline Groups & $\begin{array}{c}\text { Serum total } \\
\text { protein }(\mathrm{g} / \mathrm{dL})\end{array}$ & $\begin{array}{c}\text { Serum albumin } \\
(\mathrm{g} / \mathrm{dL})\end{array}$ & $\begin{array}{c}\text { Serum globulin } \\
\text { (g/dL) }\end{array}$ & $\mathrm{A} / \mathrm{g}$ ratio \\
\hline \multicolumn{5}{|c|}{ After 30 days (treatment) } \\
\hline Control & $7.15 \pm 0.15$ & $3.77 \pm 0.15$ & $3.37 \pm 0.12$ & $1.15 \pm 0.31$ \\
\hline Amaranth (25mg/kg) & $7.89 \pm 0.30$ & $4.14 \pm{ }^{\mathrm{NS}} 0.20$ & $3.73 \pm{ }^{\mathrm{NS}} 0.21$ & $1.12 \pm^{\mathrm{NS}} 1.82$ \\
\hline Amaranth (75mg/kg) & $8.25 \pm 0.24$ & $3.89 \pm{ }^{\mathrm{NS}} 0.14$ & $4.38 \pm *^{*} 0.37$ & $0.81 \pm{ }^{\mathrm{NS}} 0.93$ \\
\hline \multicolumn{5}{|c|}{ After 30 days (recovery period) } \\
\hline Control & $7.22 \pm 0.10$ & $3.73 \pm 0.09$ & $3.47 \pm 0.32$ & $1.02 \pm 0.42$ \\
\hline Amaranth (25mg/kg) & $7.86 \pm{ }^{\mathrm{NS}} 0.33$ & $3.63 \pm{ }^{\mathrm{NS}} 0.10$ & $4.21 \pm^{\mathrm{NS}} 0.60$ & $0.88 \pm{ }^{\mathrm{NS}} 0.46$ \\
\hline Amaranth (75mg/kg) & $8.36 \pm \pm^{\mathrm{NS}} 0.21$ & $3.91 \pm{ }^{\mathrm{NS}} 0.13$ & $4.44 \pm \pm^{\mathrm{NS}} 0.49$ & $0.91 \pm{ }^{\mathrm{NS}} 0.53$ \\
\hline
\end{tabular}

All values were expressed as mean \pm standard error.

NS (Insignificant).

* (Significant).

Serum urea and creatinine levels were determined to study the effect of amaranth on kidney function test. Data presented in table 6 show that serum urea and creatinine levels were not significantly changed in any treated groups throughout the total experimental period, as compared with the control group.

Table (6): Effect of amaranth on urea and creatinine concentrations of male albino rats.

\begin{tabular}{|c|c|c|}
\hline Groups & Serum urea $(\mathrm{mg} / \mathrm{L})$ & Serum creatinine $(\mathrm{mg} / \mathrm{L})$ \\
\hline \multicolumn{3}{|c|}{ After 30 days (treatment) } \\
\hline Control & $32.95 \pm 0.98$ & $15.39 \pm 1.61$ \\
\hline Amaranth (25mg/kg) & $33.01 \pm \pm^{\mathrm{NS}} 1.13$ & $16.11 \pm^{\mathrm{NS}} 1.95$ \\
\hline Amaranth (75mg/kg) & $36.22 \pm{ }^{\mathrm{NS}} 2.06$ & $18.39 \pm \pm^{\mathrm{NS}} 2.05$ \\
\hline \multicolumn{3}{|c|}{ After 30 days (recovery period) } \\
\hline Control & $35.35 \pm 1.08$ & $15.54 \pm 1.06$ \\
\hline Amaranth (25mg/kg) & $38.16 \pm{ }^{\mathrm{NS}} 1.66$ & $16.92 \pm^{\mathrm{NS}} 1.63$ \\
\hline Amaranth $(75 \mathrm{mg} / \mathrm{kg})$ & $36.70 \pm \pm^{\mathrm{NS}} 1.38$ & $17.09 \pm \pm^{\mathrm{NS}} 2.11$ \\
\hline
\end{tabular}

All values were expressed as mean \pm standard error.

NS (Insignificant). 


\section{DISCUSSION}

The present study is concerned with the effect of amaranth (azo dye) on some hematological and biochemical parameters on male albino rats. Amaranth has been tested by the oral route in mice, rats and dogs and by the subcutaneous route in rats. Two oral studies in rats indicating a carcinogenic effect (IARC, 1975).

The present results indicated that the percentage of body weight gain of male albino rats treated with low and high dose of amaranth recorded a marked reduction in body weight throughout the experimental periods as compared with the control. These result continued after a recovery period. The weight loss encountered in this study may be a consequence to the effect of amaranth which appears to have a hypocholesterolemic effect as revealed by a decrease in total serum cholesterol especially with the dose treated groups.

These results were in agreement with other researchers (Shaker, et al. 1989; Takeda et al.1992 and Aboel-Zahab et al.1997).

Hematological parameters are a valuable tool for assessing the injuries that caused by certain substances. The RBC count is most useful as raw data for calculation of the erythrocyte indices MCV and MCH. Decreased RBC is usually seen in anemia of any cause. Results of the present investigation revealed that erythrocytes (RBCs) count, hemoglobin $(\mathrm{Hb})$ and mean corpuscular hemoglobin concentration (MCHC) in rats treated with the high dose. These results were continued after the recovery period. These changes induced by amaranth may be due to the prevention of red blood cell synthesis via inhibition of erythropoisis in the bone marrow. In agreement with the present work, Chakravarty, et al.2005, that showed in their investigation a decreasing in hemoglobin content and total erythrocyte count at all dose levels of the food dye used. Contrary to the above, Ford, et al. 1987 stated that carmoisine (given in high doses for 6 months) did not cause any changes in the hematological investigations of rats. The marked discrepancies observed between the various research studies may be attributed to dose variations as well as the duration of colourant intake. The total leucocytic count and $\mathrm{MCH}$ in the present study remained unchanged in all experimental groups. This finding was in agreement with Borzelleca and Hallagan (1988).

Serum aminotransferases activities are known as toxicity markers in the study of hepatotoxicity caused by chemicals (Govindwar and Dalvi, 1990). An increase in the activities of these enzymes is termed as the early recognition of toxic hepatitis. Results of the present investigation revealed a marked elevation in AST and ALT activities throughout the whole experimental period in groups treated with the low and high dose of amaranth, continued after a recovery period in group treated with the high dose only.

The elevation of the aminotransferases activities in blood has been considered as an indicator of tissue damage. Similar results were reported by Abdel-Rahim et al (1989) who found significant increase in both serum AST and ALT of rats fed on brown food dye for three months, he attributed these changes in liver function to hepatocellular impairment which subsequently caused the release of greater than normal levels of intracellular enzymes into the blood.

The present study recorded an elevation in alkaline phosphatase (ALP) activity in rats treated with high dose of amaranth. The elevation in serum ALP may be an evidence of obstructive damage in the liver tissue due to amaranth administration. This observation is in agreement with that reported by Chakravarty, et al. (2005) and tot cholesterol with regard to the serum total lipids, it was found that administration of amaranth with a dose $75 \mathrm{mg} / \mathrm{kg}$ led to a significant decrease throughout the experimental period. This effect may be consequently due to the nature of the 
studied food additive which work as cholesterol - lowering agents (Ahmed, et al., 1987). The present results showed that rats administered the high dose of amaranth exhibited a significant elevation in serum glucose during the first period of the experiment. The elevation of glucose level can be explained by stimulation of glycogenolysis and gluconeogenesis by the liver with a temporarily loss of endocrine functions of pancreas leading to hyperglycemia.

Serum total protein in this study exhibited a significant increase in rats received the high dose of amaranth. In agreement with these findings EL-Saadany (1991). The accumulation of serum protein can be attributed to the stimulation of protein biosynthesis to produce the specific enzymes required for all processes. The globulin fraction in the serum of rats studied, recorded an increase induced by high dose of amaranth.

The specific elevation in globulin fraction points towards increased immunoglobin synthesis, the defense mechanism which aims to protect the body from the toxic effects of this synthetic food colourant.

The present study revealed that the blood urea and serum creatinine in rats supplemented with low and high doses of amaranth.

From the fore mentioned results, it was clear that the administration of rats to amaranth with high dose caused many disturbances in the hematological and biochemical parameters. Accordingly, more investigations are required to assess the significance of the present findings with regard to the general toxicity of amaranth in different organisms.

Finally, more extensive assessment of azo additives in general and amaranth in particular is warranted.

\section{REFERENCES}

Abdel-Rahim, E. A.; Ashoush, Y. A.; Afify, A. S. and Hewedi, F. (1989). "Effect of some synthetic food additives on blood haemoglobin and liver function of rats." Minufiya J.Agric. Res. 14(1): 557.

Aboel - Zahab, H.; El - Khyat, Z.; Sidhom, G.; Awadallah, R.; Abdel-all, W. and Mahdy, K. (1997). Physiological effects of some synthetic food colouring additives on rats. Boll. Chim . Farm. 136 (10): 615 - 627.

Ahmed, F. A.; El-Desoky, G. E.; El-Saadany, S. S. and Ramadan, M. E. (1987). Carbohydrate and lipid changes in rats ad-ministered certain synthetic and natural food colours. Minia J. Agric. Res. and Dev. 9(3). 1101

Allain, C. C.; Poon, L. S.; Chan, C. S. G.; Richmond, W. and Fu, P. C. (1974). Enzymatic determination of total serum cholesterol .Clin.Chem.20:470.

Bartels, H. and Bohmer, M. (1972). Kinetic determination of creatinine concentration. Clin. Chem. Acta, 37:193.

Belfield, A. and Golbderg, D. M. (1971). Colorimetric determination of alkaline phosphatase (ALP) activity Enzymes In: J. Clin. Chem. Clin. Biochem., 8:561.

BergMeyer, H. V. and Bernt, E. (1974). Spectrophotometric determination of amino acid transaminases In: Bergmeyerand, H. U. and Bernt, E. (Eds). Methods of Enzymatic Analysis Academic Press, Orlando F L pp. 320 - 401.

Borzelleca, J. F. and Hallagan, J. B. (1988). Chronic toxicity / carcinogenicity studies of FD \& C yellow No.5 (tratrazine) in mice. fd. chem.. Toxic. 26(3): 189.

Chakravarty, G.; Goyal, R. P.; Sharma, S. and Anjali, S. (2005). Haematological changes induced by a common non-permitted food colour malachite green (MG) in swiss albino mice. Indian J. Environ . Sci., 9 (2): 113-117. 
Combes, R. B. and Haveland - Smith, A. (1982). A review of the genotoxicity of food, drug and cosmetic colours and other azo , triphenylmethane and xanthenes dyes . Mutat. Res. 98: 101-148.

Dacie, J. V. and Lewis, S. (1991). practical haematology. 7th Ed., The English Language book society and Churchill living stone. PP.37-58.

Dacie, J. V. and Lewis, S. M. (1993). Calculation of red blood cells, haemoglobin, and erythrocyte indices in: Practical haematology. Churchill living stone,UK, PP.37-113.

Doumas, B. T. (1975). "Colorimetric determination of total protein in serum or plasma" Clin. Chem., 21 (8): 1159-1166.

Doumas, B. T.; Watson, W. A. and Biggs, H. G. (1971). "Albumin standards and measurements of serum albumin with bromocreasol green" Clin. Chem., Acta., 31: 87-96.

El-Saadany, S. S. (1991). Biochemical effect of chocolate colouring and flavouring like substances on thyroid function and protein biosynthesis. Die Nahrung 35(4): 335 .

Ford, G. P.; Stevenson, B. I. and Evans, J. G. (1987). Long-term toxicity study of carmoisine in rats using animals e-:Po-sed in utero. Fd. Chem. Toxicol, 25 (12): 919.

Govindwar, S. P. and Dalvi, R. R. (1990). Age dependent Toxicity of a corn extract in young and old male rats.Vet. Hum. Toxicol; 32:23-6.

Hirschbruch, M. D. and Torres, E. A. F. S. (1998). Toxicological de Alimentos : Uma Discussao. Hig - Alim ., 12 (53):21-25.

Holmberg, D. (1978). Effect of amaranth, Ponceau 4 R and / or vitamin A on enzyme activities of the rat liver. food Cosmet . Toxicol., 16: 1- 5.

International Agency for Research on Cancer (IARC)-Summaries \& Evaluations (1975). CAS No. 8: 915 - 967.

Knight, J. A.; Anderson, S. and Rawie, J. M. (1972). Chemical basis of the sulfophosphovaninlin reaction for estimating total serum Lipid. Clin. Chem., 18:199-202.

Lanter, A. L. (1975). Clinical Biochemistry W. B. Saunders Company,Philadelphia, $7^{\text {th }}$ edition, P.147-159.

Larsson, K. S. (1975). A teratologic study with the dyes amaranth and ponceau $4 \mathrm{R}$ in mice. Toxicology, $4: 75-82$.

Patton, C. J. and Crouch, S. R. (1977). Enzymatic determination of urea concen-tration in: Anal. Chem, 49:464-469.

Reyes, F. G. ; Valim, M. F. and Vercesi, A. E. (1996). Effect of organicsynthetic food colours on mitochondrial respiration. Food Addit. Contam. 13(1):5.

Rodak, L. C. (1995). Routine testing in haematology. In: Diagnostic haematology. W. B. London, Toronto. PP. 128-144.

Sazaki, Y. F.; Kawaguchi, S.; Kamaya, A.; Ohshima, M.; Kabasawa, K.; Iwama, K.; Taniguchi, K. and Tsuda, S. (2002). The comet assay with 8 mouse organs: Results with 39 currently used food additives. Mutat. Res. 519: 103-119.

Shaker, A. M. H.; Ismail, I. A. and El-Nemr, S. E. (1989). Effect of different foodstuff colourants added to casein diet for biological evaluation. Bull.Nutr. Inst .Cairo, Egypt. 9(1): 77.

Snedecor, G. W. and Cochran, W. G. (1980). Statistical methods. Oxford and J. 13. H. Publishing Co., $7^{\text {th }}$ Ed. 
Takeda, H.; Nakajima, A. and Kiriyama, S. (1992). Beneficial effects of dietary fiber on the upper gastrointestinal transit time in rats suffering from toxic dose of amaranth . Biosci . Biotech. Biochem. 56: 551-555.

Tanaka, T. (2005). Reproductive and neurobehavioural toxicity study of trartrazine administration to mice in the diet. Food Chem . Toxicol. 5: 16-25.

Toledo, M. C. F. (1999). Regulamentacao de uso de corantes Naturis . Arch . Lantinoam Nutr. 49 (1): 67-70.

Trinder, P. (1969). Determination of glucose in blood using glucose oxidase with an alternative acceptor. Ann. Clin. Biochem., 6:24-27.

Tsuda, S.; Murakami, M.; Matsusaka, N.; Kano, K.; Taniguchi, K. and Sasaki, Y. F. (2001): DNA damage induced by red food dyes orally administered to pregnant and male mice. Toxicological Sciences, 61: 92-99.

Zraly, Z.; Pisarikova, B.; Trckova, M.; Herzig, I.; Juzl, M. and Simeonovova, J. (2006). Effect of lupin and amaranth on growth efficiency, health and carcass characteristics and meat quality of market pigs. Acta Veterinaria Brno. 75 (3): $363-372$.

\section{ARABIC SUMMARY}

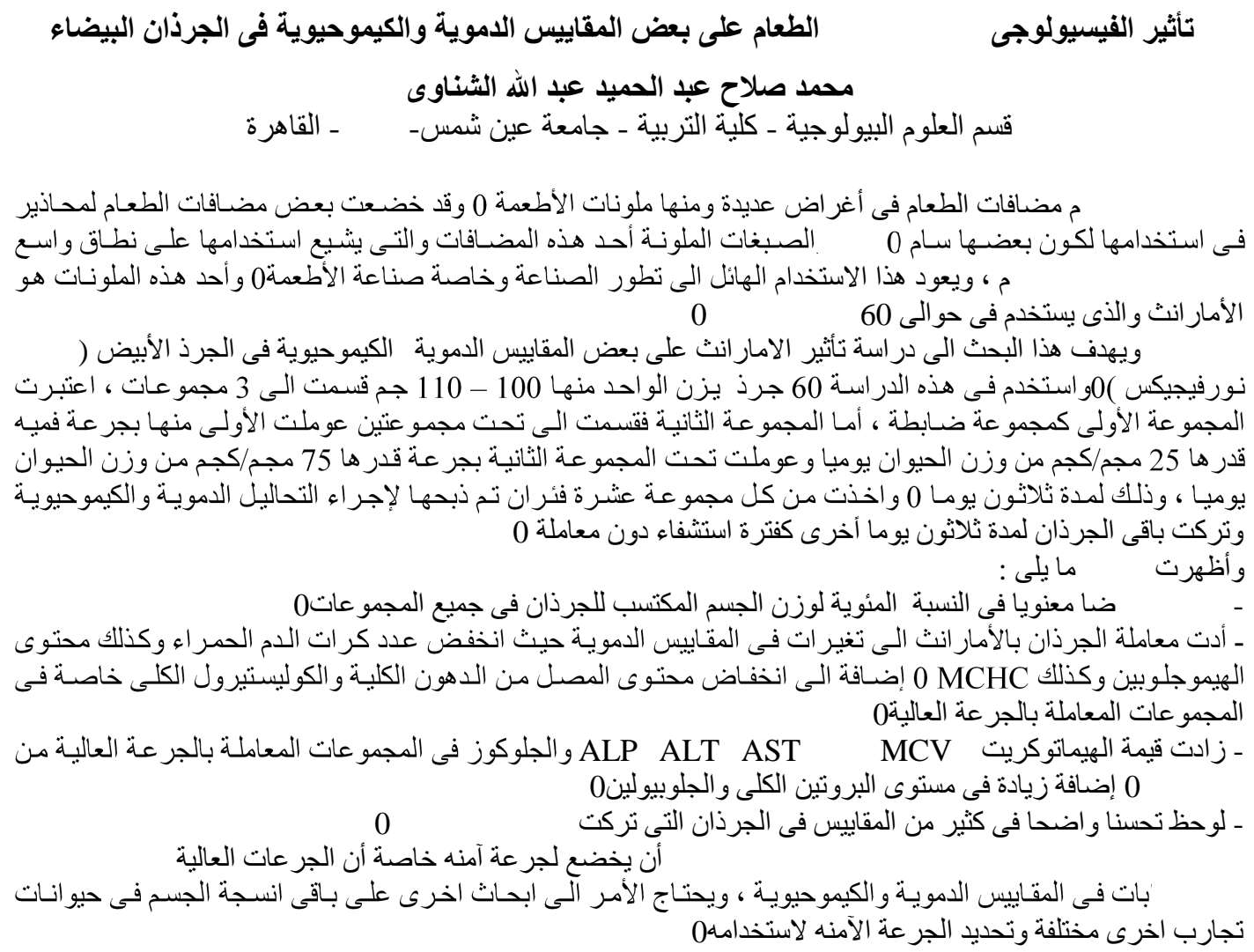

